\title{
Topographic Variation in Forest Expansion Processes across a Mosaic Landscape in Western Canada
}

\author{
Larissa Robinov $^{1}$, Chris Hopkinson ${ }^{2}$ (D) and Mark C. Vanderwel ${ }^{1, *}$ \\ 1 Department of Biology, University of Regina, Regina, SK S4S 0A2, Canada; lrr205@uregina.ca \\ 2 Department of Geography, University of Lethbridge, Lethbridge, AB T1K 3M4, Canada; c.hopkinson@uleth.ca \\ * Correspondence: mark.vanderwel@uregina.ca; Tel.: +1-306-337-2544; Fax: +1-306-337-2410
}

Citation: Robinov, L.; Hopkinson, C.; Vanderwel, M.C. Topographic Variation in Forest Expansion Processes across a Mosaic Landscape in Western Canada. Land 2021, 10, 1355. https://doi.org/10.3390/ land 10121355

Academic Editor: Svetlana Turubanova

Received: 14 October 2021

Accepted: 4 December 2021

Published: 8 December 2021

Publisher's Note: MDPI stays neutral with regard to jurisdictional claims in published maps and institutional affiliations.

Copyright: (c) 2021 by the authors. Licensee MDPI, Basel, Switzerland. This article is an open access article distributed under the terms and conditions of the Creative Commons Attribution (CC BY) license (https:// creativecommons.org/licenses/by/ $4.0 /)$.

\begin{abstract}
Changes to historic fire and grazing regimes have been associated with the expansion of tree cover at forest-grassland boundaries. We evaluated forest expansion across a mosaic landscape in western Canada using aerial photos, airborne laser scanning, and field transects. The annual rate of forest expansion $(0.12 \%)$ was on the low end of rates documented across North America and was greater from the 1970s to the 1990s than from the 1990s to 2018. Most forest expansion occurred within $50 \mathrm{~m}$ of established forests, and $68 \%$ of all tree regeneration in grasslands was within $15 \mathrm{~m}$ of the forest edge. The intensity of cattle grazing did not affect the tree regeneration density. Despite the slow pace of land cover change, grassland areas near the forest edge had an average of $20 \%$ canopy cover and $9 \mathrm{~m}$ canopy height, indicating the presence of tall but sporadic trees. The rate of forest expansion, density of tree regeneration, and tree cover within grasslands were all greater at lower elevations where trembling aspen (Populus tremuloides) and white spruce (Picea glauca) were the dominant tree species. We conclude that proportions of forest-grassland cover on this landscape are not expected to change dramatically in the absence of major fire over the next several decades.
\end{abstract}

Keywords: grassland; forest structure; tree regeneration; grazing; remote sensing; aerial photography; airborne laser scanning; lidar

\section{Introduction}

Forest expansion into grasslands has been observed around the globe at varying rates [1-4]. Forest expansion is a subcategory of woody plant encroachment and can be defined as an increase in density, cover, or biomass of trees in vegetation types where they were not previously found [4-6]. Rates of woody plant encroachment into grasslands in North America range from $<0.1$ to $2.3 \%$ per year [5] and there is concern for the long-term implications of such land cover change. Grasslands are one of the most at-risk biomes for habitat loss with over half of the world's temperate grasslands already developed or converted to other land uses [7]. There is also uncertainty in how aggregate shifts from herbaceous to woody plant cover affect terrestrial carbon stocks [8]. A better understanding of the factors that influence forest expansion processes would help in projecting future land cover change as well as its effects on carbon stocks [5] and habitat availability.

Rates and patterns of forest expansion vary across ecoregions, and even within landscapes [6,9]. Mean annual precipitation broadly determines the proportional coverage of different vegetation types (e.g., woody and herbaceous species). Sankaran et al. [10] identified a precipitation threshold of $650(+/-134) \mathrm{mm} / \mathrm{yr}$, where mosaic landscapes with annual precipitation levels greater than this value were climatically determined. Areas with lower precipitation were considered to be disturbance-driven, meaning fire, grazing, and browsing were required to maintain the presence of both trees and grasses. Moisture availability also influences tree establishment and development in semi-arid climates [11-13], and it has been hypothesized that moisture and temperature limitations help to maintain forest-grassland boundaries [14-17]. 
Variable rates of expansion and both abrupt and diffuse forest edges have been observed on the same landscape $[18,19]$, which indicates that factors operating at the local scale can affect tree-line boundaries in addition to regional influences such as precipitation. Due to topography and vegetation cover, local moisture levels and temperatures present differently across heterogeneous landscapes, which can create microclimates and alter soil properties [20-23]. By looking at historical aerial photographs paired with other remote sensing tools, such as digital elevation models (DEMs), researchers have found that aspect [1,3,24], elevation [1,2], and slope [2,24,25] can influence the rate and extent of forest expansion. These relationships with topography have been attributed primarily to thermal and moisture limitations, as woody plant expansion within arid and semi-arid environments tends to occur more rapidly in areas that experience greater moisture and moderate temperatures $[18,19]$.

Forest expansion and subsequent development are limited by the establishment of regeneration beyond the existing canopy. The tree seedling and sucker stages are considered the bottleneck stages of development $[15,21,26]$, as it is when woody species are most sensitive to moisture, temperature, fire, and browsing [27-29]. The insulating effects of woody vegetation on environmental conditions facilitate tree-line expansion. Relative humidity is higher in forests compared with clearings due to decreased wind velocities and more stable air temperatures, with the greatest change in conditions occurring near the forest edge $[16,30]$. The magnitude of change in temperature and moisture can also vary with topography (particularly aspect) with insulating edge effects being most pronounced on southwest-facing aspects and lowest on northeast-facing aspects [31]. Conditions at forest edges are likely to be more favorable to tree establishment and development than those in open grassland areas. The distance from the forest edge at which high densities of regeneration can successfully establish is likely to affect rates of forest expansion [32,33].

The process of grassland-forest transition begins with pioneer species establishing in grassland areas. The local microclimate starts to change with the growth of woody species, producing a nucleating effect and an increase in tree establishment that leads to further infilling in the adjacent grassland [34-36]. Tree height and cover increase over time until grassland areas with sporadic tree cover develop into closed-canopy forest. As more regeneration establishes, the forest-grassland boundary gradually advances and interior conditions eventually develop at the former edge. Differences between edge and interior conditions can result in different patterns of stand structural development [37].

In addition to climatic factors, tree-lines may be influenced by disturbances such as herbivory and fire $[24,38,39]$. Fire and herbivory have also been considered a single disturbance regime because of their intrinsic interactions, referred to as pyric herbivory [40,41]. In western North America, these natural disturbance agents of grassland ecosystems were greatly altered by the near-extinction of bison and suppression of most fires [42,43]. Fire return intervals increased over the 20th century, leading to greater tree cover $[24,39,44]$. Grazing by wild and domestic ungulates has continued but is now influencing vegetation independently of fire on many landscapes. Large grazers can either facilitate tree establishment through preferential grazing of grasses and seed dispersal or hinder it through trampling and browsing. Previous studies have reported positive [45], neutral [46], and negative [47] effects of grazing on woody plant expansion.

In the present study, we use a combination of remote sensing and field data to evaluate the nature and rate of forest expansion across a mixed forest-grassland landscape in western Canada. Our specific research questions are: (1) In recent decades, what was the probability of land cover change at a given distance from the forest edge? (2) How does the canopy structure (height, cover) of newly forested areas compare with that in pre-existing forests and adjacent grassland areas? (3) How prevalent is tree regeneration in grassland areas at varying distances from the forest edge? (4) How do elevation, slope, and aspect influence each of the above? (5) Is regeneration density in grassland areas related to grazer activity? 


\section{Methods}

\subsection{Study Area}

The western portion of Cypress Hills Interprovincial Park encompasses a $348 \mathrm{~km}^{2}$ area in southwestern Saskatchewan and southeastern Alberta, Canada $\left(49^{\circ} 37^{\prime} \mathrm{N}, 110^{\circ} 0^{\prime} \mathrm{W}\right)$ (Figure 1). This area ranges from 1100 to $1450 \mathrm{~m}$ in elevation, rising an average of $250 \mathrm{~m}$ above surrounding agricultural and range lands. The average annual temperature and precipitation are $3.3^{\circ} \mathrm{C}$ and $600 \mathrm{~mm}$, respectively [48]. The warmest month is July with an average daily temperature of $15.9^{\circ} \mathrm{C}$. June and July are the months with the highest rainfall (103 $\mathrm{mm}$ and $60 \mathrm{~mm}$, respectively), and $42 \%$ of all precipitation comes from snowfall.
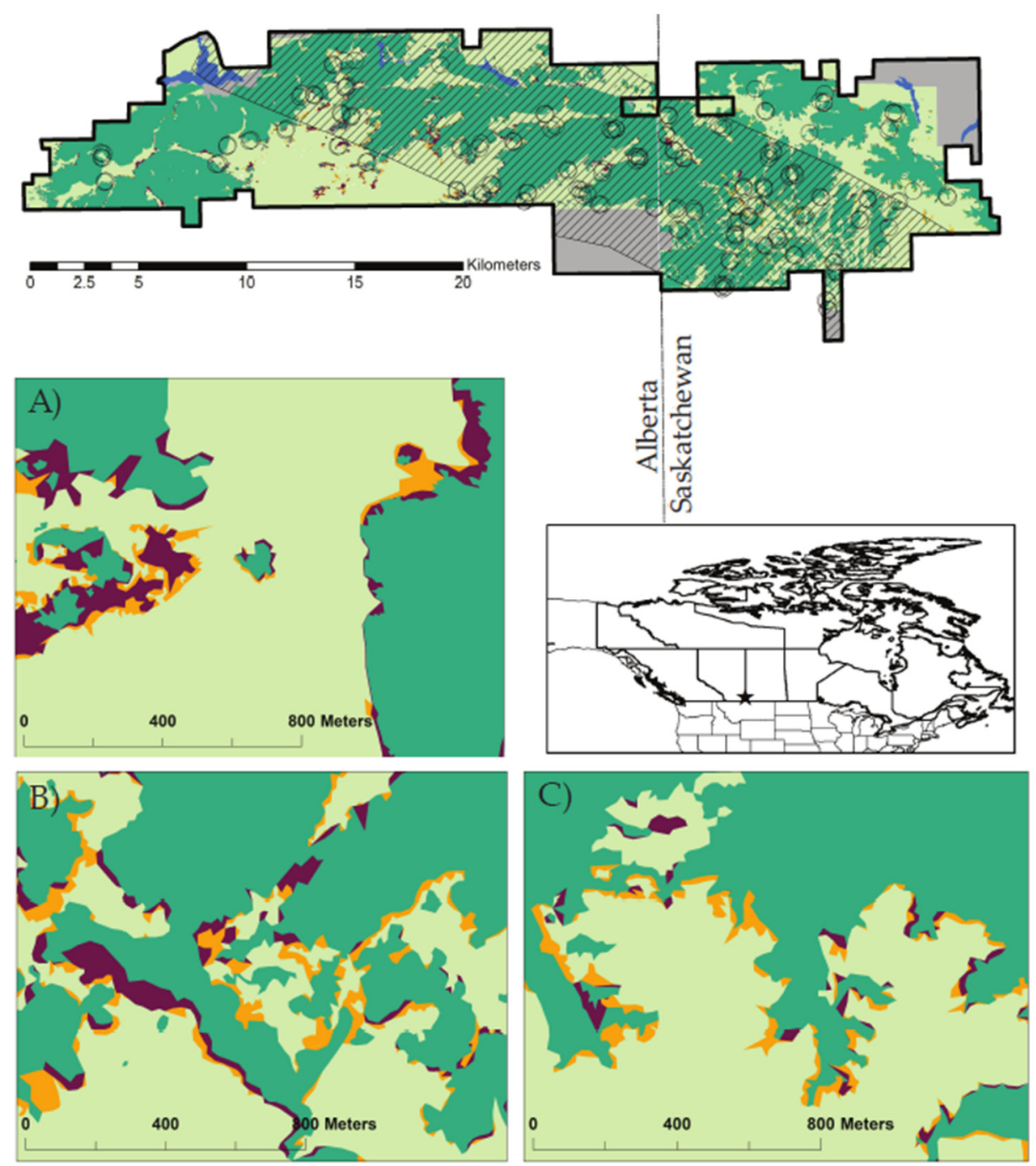

Legend

Transect sites

ALS coverage

Water

No imagery data
Forest extent in 1970s

Forest extent in time interval 1

Forest extent in time interval 2

Grasslands

Figure 1. Land cover type and data coverage within Cypress Hills Interprovincial Park. Panels show example areas of land cover change (A) on the western plateau, (B) in the Battle Creek valley, and (C) on the eastern plateau.

The Cypress Hills landscape is a mosaic of forests and grasslands. Three tree species dominate the park's forest stands: trembling aspen (Populus tremuloides Michx.) and white 
spruce (Picea glauca (Moench) Voss) stands occupy the valleys and lower slopes, and lodgepole pine (Pinus contorta Dougl.) stands are found at higher elevations. The two main grassland types are rough fescue-dominated grasslands on upper plateaus, and mixedgrass prairie (Stipa spp. L., Bouteloua gracillis (Kunth), Koeleria cristata Pers., Agropyron dasystachyum (Hook.)) on drier slopes and at lower elevations [49,50]. The oldest forest stands originated from fires in 1885 and 1889, which were the last major fires in the park. Bison were extirpated from the landscape in the early 1880s, and elk and moose were introduced in the 1930s and 1940s [49]. Permitted grazing by domestic cattle began in 1918 and four different stock associations presently hold grazing permits.

\subsection{Data Collection and Processing}

\subsubsection{Aerial Photographs}

We used historical (1976-1979, 1991-1998) and contemporary (2018) aerial photographs to quantify land cover change. The number, resolution, and year of acquisition of aerial photo data varied between the two provinces (Table 1). The 2018 tiles were provided in color and were already georeferenced and orthorectified. The historical photos were scanned, individual, panchromatic, raw photos from flight surveys. Georectification of those photos was done in ArcGIS (ArcGIS 10.8; Esri software) using a spline transformation with an average of 35 control points per image, evenly spaced across each photo. Orthorectification was carried out using the ArcGIS Block Adjustment toolbar and a 25-m resolution digital elevation model. The average georeferencing error in the alignment of forest edges for historical and contemporary orthomosaics was $3.7 \mathrm{~m}$ (range: $2.5-5.3 \mathrm{~m}$ ). Varying greyscale and shadows in the historical imagery, which arose from complex topography and the presence of shrubland, produced several errors during attempts at both supervised pixel-based classification and object-based classification. The best land cover classification results were achieved with manual digitization, and so this was the methodology we used. Vector shapefiles with areas representing forest, grassland, and water land cover types were created from each orthomosaic (Figure 1). We defined forests as being $\geq 0.5$ ha in size and having $\geq 50 \%$ canopy cover. This size threshold is used by the Food and Agriculture Organization (FAO) of the United Nations, while a 50\% cover threshold was easiest to assess visually in aerial photographs and during field work. Forest openings $>0.5$ ha were delineated to evaluate infilling, but smaller forest gaps were ignored. For consistency, forest areas that were subjected to harvesting or thinning were classified as forest in all images.

Table 1. Specifications for aerial photo data used to assess land cover change.

\begin{tabular}{cccccccc}
\hline $\begin{array}{c}\text { Acquisition } \\
\text { Year }\end{array}$ & Province & $\begin{array}{c}\text { Number of } \\
\text { Photos or Tiles }\end{array}$ & Scale & Color & Resolution (m) & $\begin{array}{c}\text { Georeferencing } \\
\text { Error }\end{array}$ & Source $* * *$ \\
\hline 1976 & Alberta & 77 & $1: 12,000$ & Monochromatic & 0.27 & 2.55 & AAPRS \\
1998 & Alberta & 20 & $1: 30,000$ & Monochromatic & 0.66 & 3.28 & AAPRS \\
2018 & Alberta & 12 & N/A & Red, green, blue & 0.25 & 0.00 & TRS \\
1979 & Saskatchewan & 4 & $1: 20,000$ & Monochromatic & 1.70 & SMPCS \\
1991 & Saskatchewan & 42 & $1: 21,000$ & Monochromatic & 0.87 & 3.83 & SMPCS \\
2018 & Saskatchewan & 6 & N/A & Red, green, blue & 0.3 & 0.00 & SMPCS \\
\hline
\end{tabular}

${ }^{*}$ Scale not applicable for digital imagery, ${ }^{* *}$ Root mean squared error (RMSE) relative to the 2018 reference layer, ${ }^{* * *}$ AAPRS, Alberta Aerial Photographic Record System; TRS, Tarin Resource Services; SMPCS, Saskatchewan Ministry of Parks, Culture, and Sport.

We defined two time intervals for land cover change based on the years of aerial photo acquisition: interval 1 represented the period 1976-1998 in Alberta and 1979-1991 in Saskatchewan (hereafter referred to as 1970s-1990s); interval 2 represented the period 1998-2018 in Alberta and 1991-2018 in Saskatchewan (referred to as 1990s-2018). We refer to areas that were forested at the start of interval 1 as pre-existing forests and areas that were forested at the end of interval 2 as present forests.

We rasterized the vector-based land classification at a $25-\mathrm{m}$ resolution to match that of the digital elevation data available for the study area [51]. At this resolution, data were less sensitive to georeferencing errors (which were generally less than $5 \mathrm{~m}$ ) and errors in 
precisely delineating the forest boundary in areas where it is diffuse. Cells with $\geq 50 \%$ forest cover were classified as forest, and cells with $<50 \%$ forest cover as grassland. We subset the raster data before fitting statistical models of forest expansion by (1) discarding cells representing pre-existing forest or water, since these would not transition to forest cover through forest expansion; (2) discarding cells $>2 \mathrm{~km}$ from the forest edge, since no cells were observed to transition to forest at this distance from pre-existing forest; and (3) retaining every eighth horizontal and vertical cell (i.e., $200 \mathrm{~m}$ separation) to better ensure spatial independence. We tested the latter assumption by fitting a preliminary binomial generalized linear model, with forest cover after interval 1 as the response and distance to present forest, elevation, and their two-way interaction as predictor variables. Residuals from this model showed very weak autocorrelation at a distance of $200 \mathrm{~m}$ (Moran's I = 0.02).

\subsubsection{Airborne Laser Scanning}

We collected airborne laser scanning data across approximately $75 \%$ of the study area in August 2015 (Figure 1). We used these data to measure canopy height and cover, but did not use it as a source of topographic information because of incomplete coverage. Laser pulse returns with a point density of $0.5 \mathrm{pts} / \mathrm{m}^{2}$ were acquired using an Optech Aquarius sensor operating at a wavelength of $532 \mathrm{~nm}$. We used the lidR package in R [52] to classify the resulting point cloud into ground and non-ground returns, and to normalize the points to represent height above ground level. We then overlaid the point cloud with five land cover classes derived from the classified aerial imagery: (1) pre-existing forests; (2) areas that became forested during interval 1 (1970s-1990s); (3) areas that became forested during interval 2 (1990s-2018); (4) grassland areas within $50 \mathrm{~m}$ of the present forest edge; and (5) grassland areas that are more than $50 \mathrm{~m}$ from the present forest edge. Next, we grouped the point cloud into a set of spatial clusters in order to calculate canopy cover and canopy height for distinct areas and later model them against topographic predictor variables. To do this, we used a k-means clustering algorithm to assign all laser returns into one of 8357 spatial clusters based on their $x-y$ coordinates. We chose the number of clusters in each land cover class so that each encompassed a mean area of 1 ha $(n=3219,353,179$, 1242 , and 3364 for the five classes defined above, respectively) and contained sufficient points to reliably estimate canopy cover and height. We then decimated the points to a uniform spatial density and computed the 95th percentile of non-ground return height (hereafter, upper canopy height), and the proportion of returns with height $\geq 2 \mathrm{~m}$ (hereafter, canopy cover) within each cluster.

\subsubsection{Regeneration and Scat Transects}

We measured tree regeneration density and grazing intensity outwards from the present forest edge in the summer of 2020. We selected 90 sites across the study area with balanced representation across topographic conditions and forest types (denoted by black circles in Figure 1), and established 1-3 belt transects at each site. Transect locations were recorded using a handheld GPS receiver (Garmin GPSMAP 64). Belt transects were $50 \mathrm{~m}$ in length, $4 \mathrm{~m}$ in width, originated at the present forest edge, and ran perpendicular to the forest into grassland (where forest was defined as having canopy cover $\geq 50 \%$ and canopy height $\geq 10 \mathrm{~m}$ ). The number of small trees (diameter at breast height $<2.5 \mathrm{~cm}$ ) of each tree species was counted in each of 10 contiguous $4 \mathrm{~m} \times 5 \mathrm{~m}$ sections along the length of each transect. Aspen suckers $<0.4 \mathrm{~m}$ in height were not counted, as they were less visible in tall grass. We also counted the total number of cow, elk, and deer scats within $0.5 \mathrm{~m}$ of the transect center line $\left(50 \mathrm{~m}^{2}\right.$ per transect). We assumed that scat remained observable for a similar amount of time for each species and that the total density of scat reflected the overall ungulate activity around each transect. 


\subsection{Statistical Analysis}

We developed generalized linear models and generalized linear mixed models to predict (1) the 20-year probability of transition from grassland to forest cover in each of our two time intervals; (2) upper canopy height and canopy cover of areas that had become forested in interval 1, interval 2, or that were presently adjacent (within $50 \mathrm{~m}$ of a forest edge) grasslands; and (3) the regeneration densities of three species (white spruce, trembling aspen, lodgepole pine) in adjacent grasslands (Table 2). Land cover change was determined by whether a location that was grassland at the start of a given time period had become forested by the end of that time period $(=1)$ or not $(=0)$. The models $(1-3)$ described how these response variables varied with elevation, slope, and aspect, as well as distance to the forest edge ( 1 and 3 only) and grazing activity ( 3 only). Table 1 provides an overview of the response and predictor variables, probability distributions, link functions, and sample sizes for each group of models. Further technical details on model formulation, selection, and Bayesian fitting can be found in Supplementary Materials.

Table 2. Summary of model features for each dataset.

\begin{tabular}{|c|c|c|c|}
\hline & Aerial Photographs & Airborne Laser Scanning & Transects \\
\hline Response variables & $\begin{array}{l}\text { Raster cell transition to forest } \\
\text { cover during interval } 1 \\
\text { Raster cell transition to forest } \\
\text { cover during interval } 2\end{array}$ & $\begin{array}{l}\text { 1. Upper canopy height of forests from interval } 1 \\
\text { 2. Upper canopy height of forests from interval } 2 \\
\text { 3. Upper canopy height in grassland within } 50 \mathrm{~m} \\
\text { of the forest edge (present) } \\
\text { 4. Canopy cover of forests from interval } 1 \\
\text { 5. Canopy cover of forests from interval } 2 \\
\text { 6. Canopy cover in grassland within } 50 \mathrm{~m} \text { of the } \\
\text { forest edge (present) }\end{array}$ & $\begin{array}{l}\text { Lodgepole pine } \\
\text { regeneration density } \\
\text { White spruce } \\
\text { regeneration density } \\
\text { Trembling aspen } \\
\text { regeneration density }\end{array}$ \\
\hline $\begin{array}{l}\text { Base model } \\
\text { predictors }\end{array}$ & Distance to closest forest edge & Intercept only & $\begin{array}{c}\text { Distance to forest edge } \\
\text { (second-order polynomial) }\end{array}$ \\
\hline $\begin{array}{l}\text { Additional } \\
\text { predictors }\end{array}$ & Elevation, slope, aspect & Elevation, slope, aspect & $\begin{array}{l}\text { Elevation, slope, } \\
\text { aspect, grazing }\end{array}$ \\
\hline Random effects & None & None & $\begin{array}{l}\text { Site-level intercept and } \\
\text { distance effect }\end{array}$ \\
\hline $\begin{array}{l}\text { Response } \\
\text { distribution }\end{array}$ & Bernoulli & Gaussian & Negative Binomial \\
\hline Link function & $\begin{array}{l}\text { Logit, with adjustment for time } \\
\text { interval length }\end{array}$ & Identity & $\log$ \\
\hline Sample size & 1. $2919 ; 2.2686$ & 1.4: 353; 2.5: 179; 3.6: 1242 & 1800 \\
\hline
\end{tabular}

${ }^{1}$ See Supplementary Materials for details.

\section{Results}

\subsection{Land Cover Change}

Across the study area, observed land cover change showed that grassland area decreased by $3.7 \%$ (548 ha) during the 1970s-1990s time interval, and by another 3.6\% (510 ha) during the 1990s-2018 interval. These changes correspond to $3.1 \%$ and $2.8 \%$ increases in forest cover, respectively. However, it is somewhat difficult to interpret these observed rates directly because of variation in the time interval lengths.

Both time periods had the same set of five best models (Table 3) for estimating land cover change. Model 9 performed especially well as the best model for interval 2 and second-best model for interval 1, so we retained it for further interpretation. Based on this model, which accounts for different time interval lengths, we estimate that $3.3 \%$ and $2.4 \%$ of grassland area was becoming forested every 20 years during interval 1 and 2, respectively (Figure 2). Conversely, we estimate that forest cover was expanding by $2.8 \%$ and $1.9 \%$ every 20 years during these respective time periods. 
Table 3. Top five models for estimating land cover change in each time interval.

\begin{tabular}{cccccc}
\hline \multicolumn{2}{c}{ Land Cover Change Models for Time Interval 1 } & \multicolumn{3}{c}{ Land Cover Change Models for Time Interval 2} \\
\hline Model & SLOO & SE & Model & $\Delta$ LOO & SE \\
\hline 6) Base model $\times(1+\mathrm{E}+\mathrm{EA}+\mathrm{NA})$ & 0 & 0 & 9) Base model $\times(1+\mathrm{E}+\mathrm{S}+\mathrm{EA}+\mathrm{NA})$ & 0 \\
9) Base model $\times(1+\mathrm{E}+\mathrm{S}+\mathrm{EA}+\mathrm{NA})$ & -0.7 & 2.0 & 7) Base model $\times(1+\mathrm{S}+\mathrm{EA}+\mathrm{NA})$ & -0.5 & 1.5 \\
10) Base model $\times(1+\mathrm{E}+\mathrm{S} \times \mathrm{EA}+\mathrm{S} \times \mathrm{NA})$ & -1.0 & 2.6 & 10) Base model $\times(1+\mathrm{E}+\mathrm{S} \times \mathrm{EA}+\mathrm{S} \times \mathrm{NA})$ & -1.6 & 0.6 \\
7) Base model $\times(1+\mathrm{S}+\mathrm{EA}+\mathrm{NA})$ & -1.3 & 3.0 & 8) Base model $\times(1+\mathrm{S} \times \mathrm{EA}+\mathrm{S} \times \mathrm{NA})$ & -1.8 & 1.5 \\
8) Base model $\times(1+\mathrm{S} \times \mathrm{EA}+\mathrm{S} \times \mathrm{NA})$ & -2.0 & 3.4 & 6) Base model $\times(1+\mathrm{E}+\mathrm{EA}+\mathrm{NA})$ & -3.8 & 2.3 \\
\hline
\end{tabular}

Notes: $\mathrm{E}=($ elevation-1300) $/ 100 ; \mathrm{S}=($ slope $/ 5) ; \mathrm{EA}$ (easterly aspect) $=\cos (90$ —aspect); NA (northerly aspect) $=\sin (90$-aspect); $\mathrm{G}=($ grazing-5) $/ 5 ; \Delta \mathrm{LOO}$ and standard error (SE) represents the difference and standard error, respectively, in expected log predictive density estimates for a new dataset.
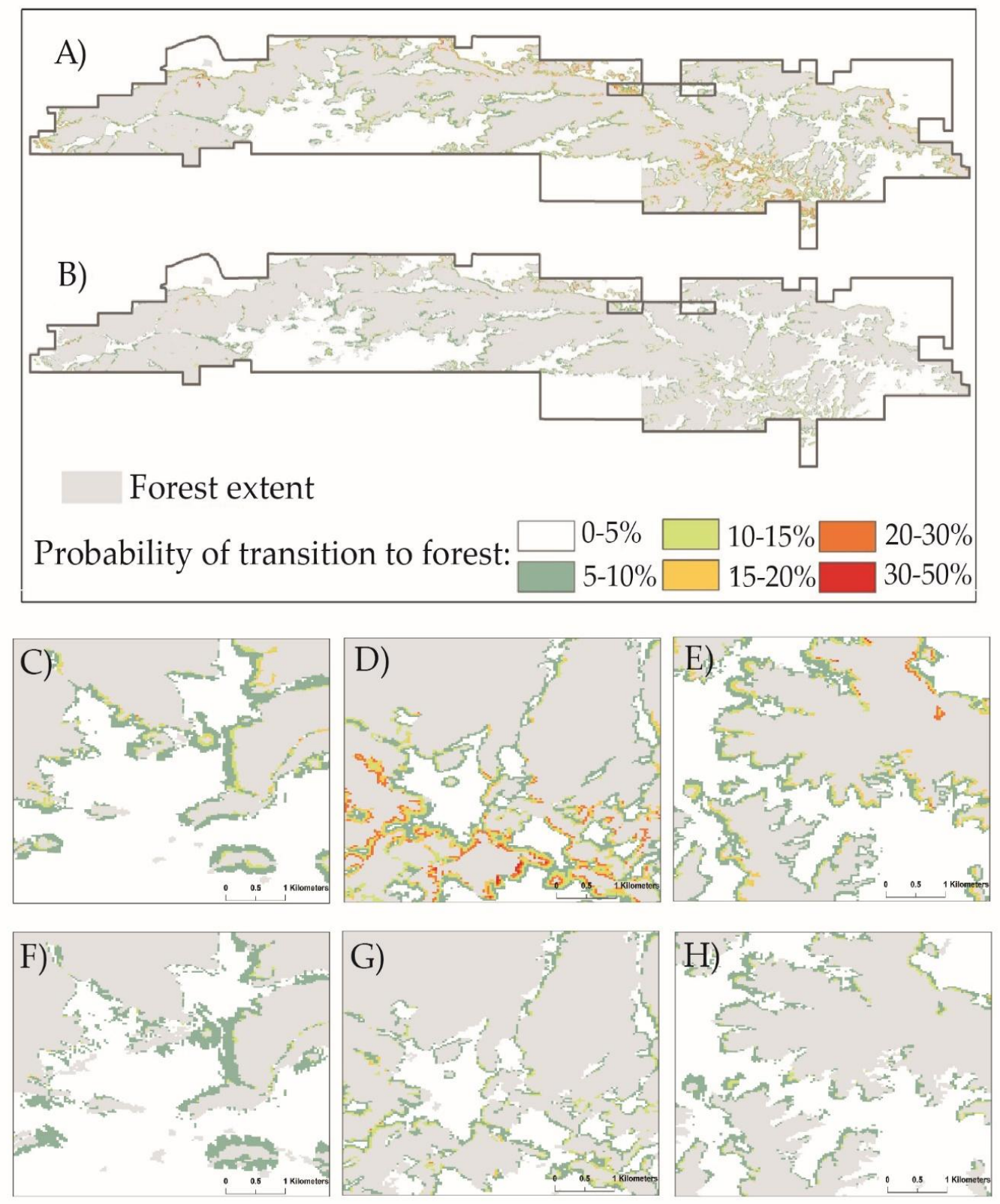

Figure 2. Map of 20-year probability of grassland cells transitioning to forest in (A) time interval 1 and (B) time interval 2. Example areas of forest transition probability are shown for interval 1 (C-E) and interval 2 (F-H). Panels represent the same areas as in Figure 1: $(\mathbf{C}, \mathbf{F})$ on the western plateau, $(\mathbf{D}, \mathbf{G})$ in the Battle Creek Valley, $(\mathbf{E}, \mathbf{H})$ on the eastern plateau. 
Models from both time periods indicate that the probability of transition to forest cover declines strongly with distance from the forest edge (Figure 3 ). The probability of a grassland cell transitioning to forest in interval 1 was $10-22 \%$ (95\% credible interval), $5-11 \%$, and $1-4 \%$ at distances $25 \mathrm{~m}, 100 \mathrm{~m}$, and $250 \mathrm{~m}$, respectively, in areas with a $1^{\circ}$ slope, a $45^{\circ}$ aspect, and $1300 \mathrm{~m}$ elevation. For interval 2 , the corresponding transition probabilities were $5-13 \%, 3-7 \%$, and $1-4 \%$.

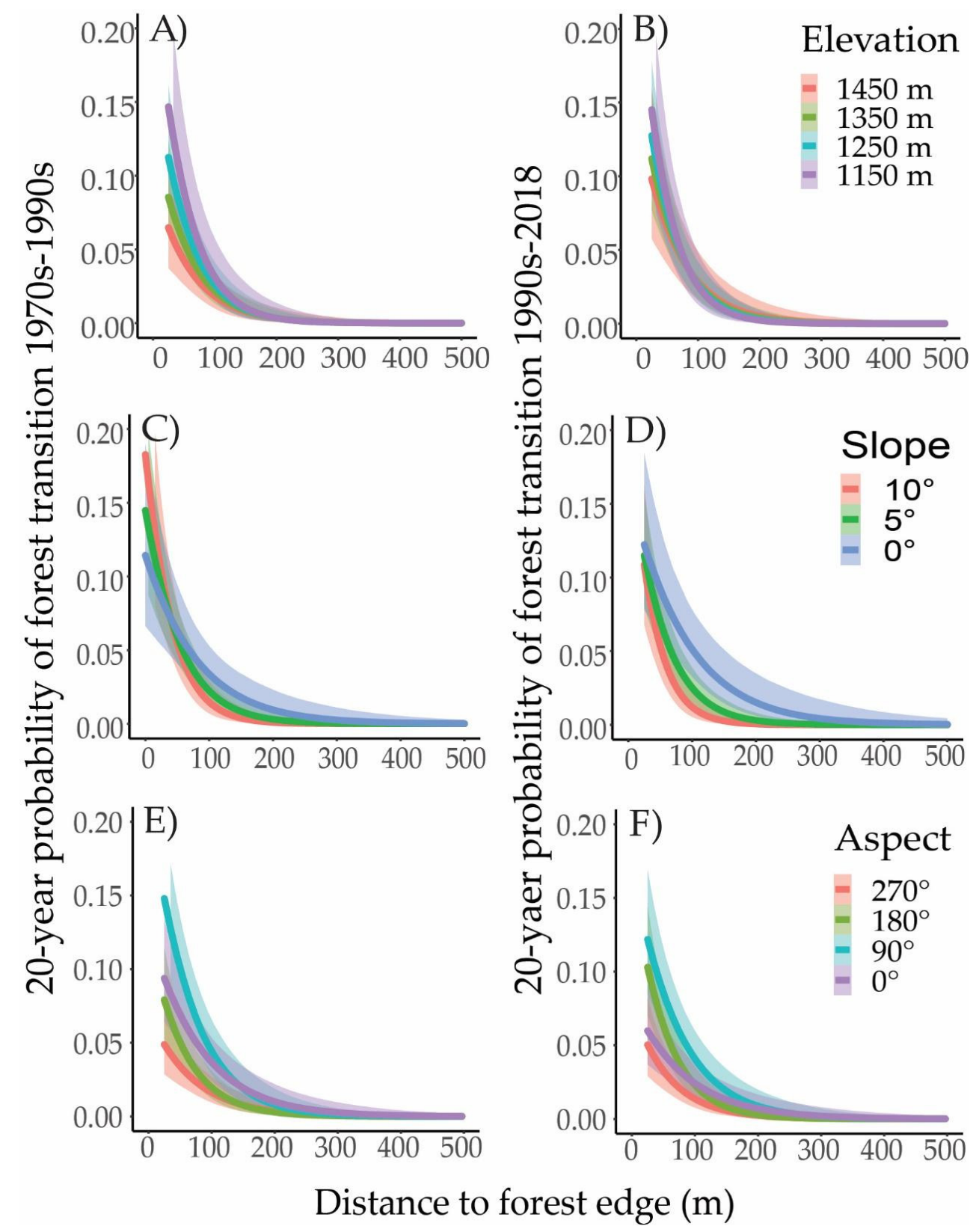

Figure 3. Changes in the 20-year probability of land cover change with increasing distance from the forest edge in interval $1(\mathbf{A}, \mathbf{C}, \mathbf{E})$ and interval $2(\mathbf{B}, \mathbf{D}, \mathbf{F})$. Lines and shaded regions represent the mean and $95 \%$ credible interval, respectively, of posterior estimates.

Flat areas at lower elevations had the highest probability of becoming forested, whereas steep, SW-facing slopes had the lowest. For example, the models estimated that grassland cells located $50 \mathrm{~m}$ from the forest edge had a $9-20 \%$ and $5-11 \%$ probability of becoming forested in intervals 1 and 2, respectively, on NE-facing $1^{\circ}$ slopes at $1250 \mathrm{~m}$ elevation. By contrast, the respective transition probabilities were only $2-5 \%$ and $1-4 \%$ for 
a SW-facing $10^{\circ}$ slope at $1400 \mathrm{~m}$ elevation. Transition probabilities dropped more quickly with increasing distance from the forest edge on steeper slopes (Figure 3). Topographic effects were similar in the two time periods, although elevation had a somewhat more pronounced effect in interval 1 compared with interval 2 (Figure 3A,B).

\subsection{Canopy Height and Cover}

There was little difference between the upper canopy height of forest areas that established from the 1970s-1990s (mean \pm s.d. $=13 \pm 2 \mathrm{~m}$ ) and those that established from the 1990s-2018 (12 $\pm 3 \mathrm{~m}$ ) (Figure 4A). The canopy height of these expanded forest areas was lower than that of pre-existing forests $(18 \pm 3 \mathrm{~m})$. Canopy height in grassland areas within $50 \mathrm{~m}$ of the present forest edge was highly variable $(9 \pm 6 \mathrm{~m})$, nearly spanning the range from present forests to open grasslands. Grasslands more than $50 \mathrm{~m}$ from the present forest edge had a mean canopy height of just $0.5 \mathrm{~m}( \pm 2 \mathrm{~m})$.

Areas that became forested in each interval had similar levels of canopy cover ( $39 \pm 10 \%$ in interval $1 ; 40 \pm 12 \%$ in interval 2 ) and were more open than pre-existing forests (canopy cover $50 \pm 9 \%$ ) (Figure $4 \mathrm{~B}$ ). Grasslands directly adjacent to the forest edge had lower but still appreciable canopy cover $(20 \pm 16 \%)$, whereas grasslands more than $50 \mathrm{~m}$ from the forest edge had virtually no canopy $(1 \pm 4 \%)$.
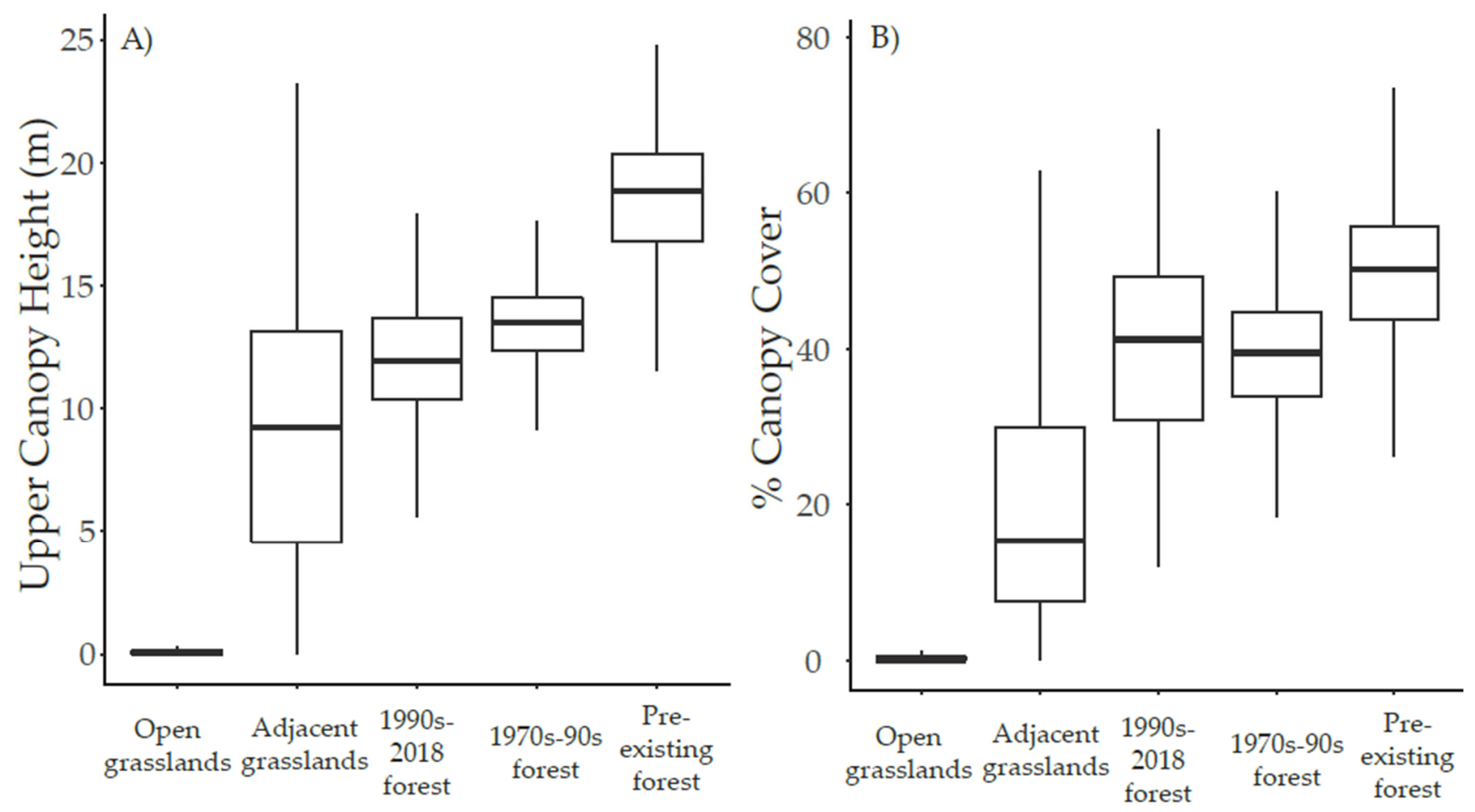

Figure 4. Distribution of (A) upper canopy height and (B) canopy cover across spatial clusters averaging 1 ha in size of different land cover classes. Lower and upper bounds of the box represent the $25 \%$ and $75 \%$ quantile, respectively. Upper and lower whiskers extend to the largest and smallest values, respectively, but no more than 1.5 times the inter-quartile range. The central line represents the median value.Relationships of canopy height and cover to topographic variables varied between the different forest and grassland classes (Table 4). The models explained almost half the variation in forests established between the 1970s-1990s but less variation was explained for the other two categories $\left(R^{2}=0.03-0.47\right)$, and only a few consistent patterns emerged.

Areas into which forests had expanded during interval 1 were predicted to be less tall and have lower cover on steep slopes than in flat areas (12-13 m and 36-39\% on a $10^{\circ}$ slope vs. $13-15 \mathrm{~m}$ and $39-42 \%$ on a $1^{\circ}$ slope). Newer forests that established during interval 2 were predicted to be taller and have greater canopy cover at lower elevations than higher ones (12-13 $\mathrm{m}$ and $42-48 \%$ at $1250 \mathrm{~m}$ vs. $9-11 \mathrm{~m}$ and $29-37 \%$ at $1450 \mathrm{~m}$ ), and 
also had somewhat higher canopy cover on NE-facing slopes. Grassland areas within $50 \mathrm{~m}$ of the forest edge were predicted to be both taller and have greater canopy cover on steep, NE-facing slopes (10-12 $\mathrm{m}$ and $22-27 \%$ on a $10^{\circ} \mathrm{NE}$ slope vs. $7-9 \mathrm{~m}$ and $15-20 \%$ on a $2^{\circ} \mathrm{W}$ slope) with canopy cover predicted to be slightly higher at lower elevations.

Table 4. Top five models for estimating upper canopy height and canopy cover for each of the three land cover classes. No single model emerged as the best fit for all categories so the top performing model in each category was selected for interpretation.

Forests Established in Time Interval 1 (1970s-1990s)

\begin{tabular}{|c|c|c|c|c|c|c|c|}
\hline \multicolumn{4}{|c|}{ Height } & \multicolumn{4}{|c|}{ Cover } \\
\hline Model * & $\Delta \mathrm{LOO}$ & SE & Bayesian $\mathrm{R}^{2}$ & Model & $\Delta \mathrm{LOO}$ & SE & Bayesian $\mathrm{R}^{2}$ \\
\hline 3) Base model $\times(1+S)$ & 0.0 & 0.0 & 0.47 & 3) Base model $\times(1+S)$ & 0.0 & 0.0 & 0.27 \\
\hline $\begin{array}{l}\text { 5) Base model } \times \\
(1+E+S)\end{array}$ & -1.4 & 0.3 & 0.49 & $\begin{array}{l}\text { 7) Base model } \times \\
(1+S+E A+N A)\end{array}$ & -0.2 & 1.8 & 0.41 \\
\hline $\begin{array}{c}\text { 8) Base model } \times \\
(1+\mathrm{S} \times \mathrm{EA}+\mathrm{S} \times \mathrm{NA})\end{array}$ & -1.7 & 2.0 & 0.68 & $\begin{array}{l}\text { 5) Base model } \times \\
(1+E+S)\end{array}$ & -1.0 & 0.8 & 0.31 \\
\hline $\begin{array}{l}\text { 7) Base model } \times \\
(1+S+E A+N A)\end{array}$ & -1.7 & 0.5 & 0.53 & $\begin{array}{c}\text { 9) Base model } \times \\
(1+E+S+E A+N A)\end{array}$ & -1.1 & 2.2 & 0.46 \\
\hline $\begin{array}{c}\text { 9) Base model } \times \\
(1+E+S+E A+N A)\end{array}$ & -3.2 & 0.7 & 0.55 & $\begin{array}{c}\text { 8) } \text { Base model } \times \\
(1+\mathrm{S} \times \mathrm{EA}+\mathrm{S} \times \mathrm{NA})\end{array}$ & -1.9 & 2.1 & 0.49 \\
\hline
\end{tabular}

Forests established in time interval 2 (1990s-2018)

\begin{tabular}{|c|c|c|c|c|c|c|c|}
\hline \multicolumn{4}{|c|}{ Height } & \multicolumn{4}{|c|}{ Cover } \\
\hline Model & $\Delta \mathrm{LOO}$ & SE & Bayesian $\mathrm{R}^{2}$ & Model & $\Delta \mathrm{LOO}$ & SE & Bayesian $\mathrm{R}^{2}$ \\
\hline 2) Base model $\times(1+E)$ & 0.0 & 0.0 & 0.13 & $\begin{array}{l}\text { 6) Base model } \times \\
(1+E+E A+N A)\end{array}$ & 0.0 & 0.0 & 0.20 \\
\hline $\begin{array}{l}\text { 5) Base model } \times \\
(1+E+S)\end{array}$ & -1.0 & 0.3 & 0.13 & $\begin{array}{c}\text { 9) Base model } \times \\
(1+E+S+E A+N A)\end{array}$ & -0.8 & 0.3 & 0.21 \\
\hline $\begin{array}{l}\text { 6) Base model } \times \\
(1+E+E A+N A)\end{array}$ & -1.7 & 0.9 & 0.14 & $\begin{array}{c}\text { 10) } \text { Base model } \times \\
(1+\mathrm{E}+\mathrm{S} \times \mathrm{EA}+\mathrm{S} \times \mathrm{NA})\end{array}$ & -0.9 & 1.9 & 0.23 \\
\hline $\begin{array}{c}\text { 9) Base model } \times \\
(1+E+S+E A+N A)\end{array}$ & -2.8 & 0.9 & 0.14 & 2) Base model $\times(1+E)$ & -1.5 & 2.6 & 0.17 \\
\hline $\begin{array}{c}\text { 10) } \text { Base model } \times \\
(1+\mathrm{E}+\mathrm{S} \times \mathrm{EA}+\mathrm{S} \times \mathrm{NA})\end{array}$ & -3.4 & 1.8 & 0.16 & $\begin{array}{l}\text { 5) } \text { Base model } \times \\
(1+E+S)\end{array}$ & -2.4 & 2.6 & 0.17 \\
\hline
\end{tabular}

Grasslands within $50 \mathrm{~m}$ of the forest edge

\begin{tabular}{|c|c|c|c|c|c|c|c|}
\hline \multicolumn{4}{|c|}{ Height } & \multicolumn{4}{|c|}{ Cover } \\
\hline Model & $\Delta \mathrm{LOO}$ & SE & Bayesian $\mathrm{R}^{2}$ & Model & $\Delta \mathrm{LOO}$ & SE & Bayesian $R^{2}$ \\
\hline $\begin{array}{c}\text { 8) Base model } \times \\
(1+\mathrm{S} \times \mathrm{EA}+\mathrm{S} \times \mathrm{NA})\end{array}$ & 0.0 & 0.0 & 0.03 & $\begin{array}{c}\text { 10) } \text { Base model } \times \\
(1+\mathrm{E}+\mathrm{S} \times \mathrm{EA}+\mathrm{S} \times \mathrm{NA})\end{array}$ & 0.0 & 0.0 & 0.04 \\
\hline $\begin{array}{c}\text { 10) } \text { Base model } \times \\
(1+E+S \times E A+S \times N A)\end{array}$ & -0.8 & 0.3 & 0.03 & $\begin{array}{c}\text { 8) Base model } \times \\
(1+\mathrm{S} \times \mathrm{EA}+\mathrm{S} \times \mathrm{NA})\end{array}$ & -0.6 & 1.8 & 0.03 \\
\hline $\begin{array}{l}\text { 7) Base model } \times \\
(1+S+E A+N A)\end{array}$ & -1.1 & 2.5 & 0.02 & $\begin{array}{c}\text { 9) Base model } \times \\
(1+E+S+E A+N A)\end{array}$ & -3.6 & 3.1 & 0.03 \\
\hline $\begin{array}{c}\text { 9) Base model } \times \\
(1+E+S+E A+N A)\end{array}$ & -2.0 & 2.5 & 0.02 & $\begin{array}{l}\text { 7) Base model } \times \\
(1+S+E A+N A)\end{array}$ & -4.5 & 3.6 & 0.02 \\
\hline 3) Base model $\times(1+S)$ & -3.9 & 4.2 & 0.01 & $\begin{array}{l}\text { 5) } \text { Base model } \times \\
(1+E+S)\end{array}$ & -6.9 & 4.8 & 0.02 \\
\hline
\end{tabular}

* See Table 3 for symbol definitions and for $\Delta \mathrm{LOO}$ and standard error (SE) definitions. Bayesian $\mathrm{R}^{2}$ measures the goodness-of-fit for each model.

\subsection{Regeneration Establishment}

We recorded average regeneration densities of 132 stems/ha for white spruce, 1803 stems/ha for trembling aspen, and 101 stems/ha for lodgepole pine in grasslands within $50 \mathrm{~m}$ of the forest edge. The highest regeneration densities occurred next to the forest edge, with only $32 \%$ of all seedlings and suckers located further than $15 \mathrm{~m}$ into the grassland. While there was some variation in model preference between species, we retained the model 
that omitted grazing and a slope $\times$ aspect interaction for interpretation as its LOO values were within one standard error of the best model for each species (Table 5).

Table 5. Top five models for estimating white spruce, trembling aspen, and lodgepole pine regeneration density.

\begin{tabular}{|c|c|c|c|c|c|c|c|c|}
\hline \multicolumn{3}{|l|}{ White Spruce } & \multicolumn{3}{|l|}{ Trembling Aspen } & \multicolumn{3}{|c|}{ Lodgepole Pine } \\
\hline Model & $\Delta \mathrm{LOO}$ & SE & Model & $\triangle \mathrm{LOO}$ & SE & Model & $\Delta \mathrm{LOO}$ & SE \\
\hline $\begin{array}{c}\text { 10) Base model } \times \\
(1+E+S \times E A+S \times N A)\end{array}$ & 0.0 & 0.0 & $\begin{array}{l}\text { 9) Base model } \times \\
(1+E+S+E A+N A)\end{array}$ & 0.0 & 0.0 & $\begin{array}{c}\text { 16) Base model } \times \\
(1+E+E A+N A)+G\end{array}$ & 0.0 & 0.0 \\
\hline $\begin{array}{c}\text { 18) Base model } \times \\
(1+E+S+E A+N A)+G\end{array}$ & 0.0 & 1.5 & $\begin{array}{c}\text { 10) } \text { Base model } \times \\
(1+\mathrm{E}+\mathrm{S} \times \mathrm{EA}+\mathrm{S} \times \mathrm{NA})\end{array}$ & -0.1 & 1.0 & $\begin{array}{c}\text { 18) Base model } \times \\
(1+E+S+E A+N A)+G\end{array}$ & 0.0 & 0.9 \\
\hline $\begin{array}{l}\text { 9) Base model } \times \\
(1+E+S+E A+N A)\end{array}$ & -0.3 & 1.4 & $\begin{array}{l}\text { 15) Base model } \times \\
(1+E+S)+G\end{array}$ & -0.6 & 1.0 & $\begin{array}{l}\text { 6) Base model } \times \\
(1+E+E A+N A)\end{array}$ & -0.3 & 1.3 \\
\hline $\begin{array}{c}\text { 20) Base model } \times \\
(1+\mathrm{E}+\mathrm{S} \times \mathrm{EA}+\mathrm{S} \times \mathrm{NA})+\mathrm{G}\end{array}$ & -0.4 & 0.9 & $\begin{array}{c}\text { 16) Base model } \times \\
(1+E+E A+N A)+G\end{array}$ & -0.6 & 1.5 & $\begin{array}{l}\text { 9) Base model } \times \\
(1+E+S+E A+N A)\end{array}$ & -1.0 & 1.6 \\
\hline $\begin{array}{c}\text { 8) Base model } \times \\
(1+\mathrm{S} \times \mathrm{EA}+\mathrm{S} \times \mathrm{NA})\end{array}$ & -1.6 & 1.9 & $\begin{array}{c}\text { 20) Base model } \times \\
(1+\mathrm{E}+\mathrm{S} \times \mathrm{EA}+\mathrm{S} \times \mathrm{NA})+\mathrm{G}\end{array}$ & -0.7 & 1.3 & $\begin{array}{l}\text { 15) Base model } \times \\
(1+E+S)+G\end{array}$ & -1.0 & 2.8 \\
\hline
\end{tabular}

Notes: See Table 3 for symbol definitions and for $\triangle \mathrm{LOO}$ and SE definitions.

The density of regeneration decreased with distance from the forest edge for all three species, but especially white spruce and trembling aspen (Figure 5). At a distance of $25 \mathrm{~m}$, the predicted densities of white spruce, trembling aspen, and lodgepole pine were, on average, $6 \%, 3 \%$, and $47 \%$ of their respective densities $5 \mathrm{~m}$ from the forest edge. With the exception of lodgepole pine, the majority of transects ( $76 \%$ of 180 transects for white spruce, $91 \%$ for trembling aspen, $34 \%$ for lodgepole pine) had predicted regeneration densities at $25 \mathrm{~m}$ that were less than $20 \%$ of the densities estimated at a $5 \mathrm{~m}$ distance.
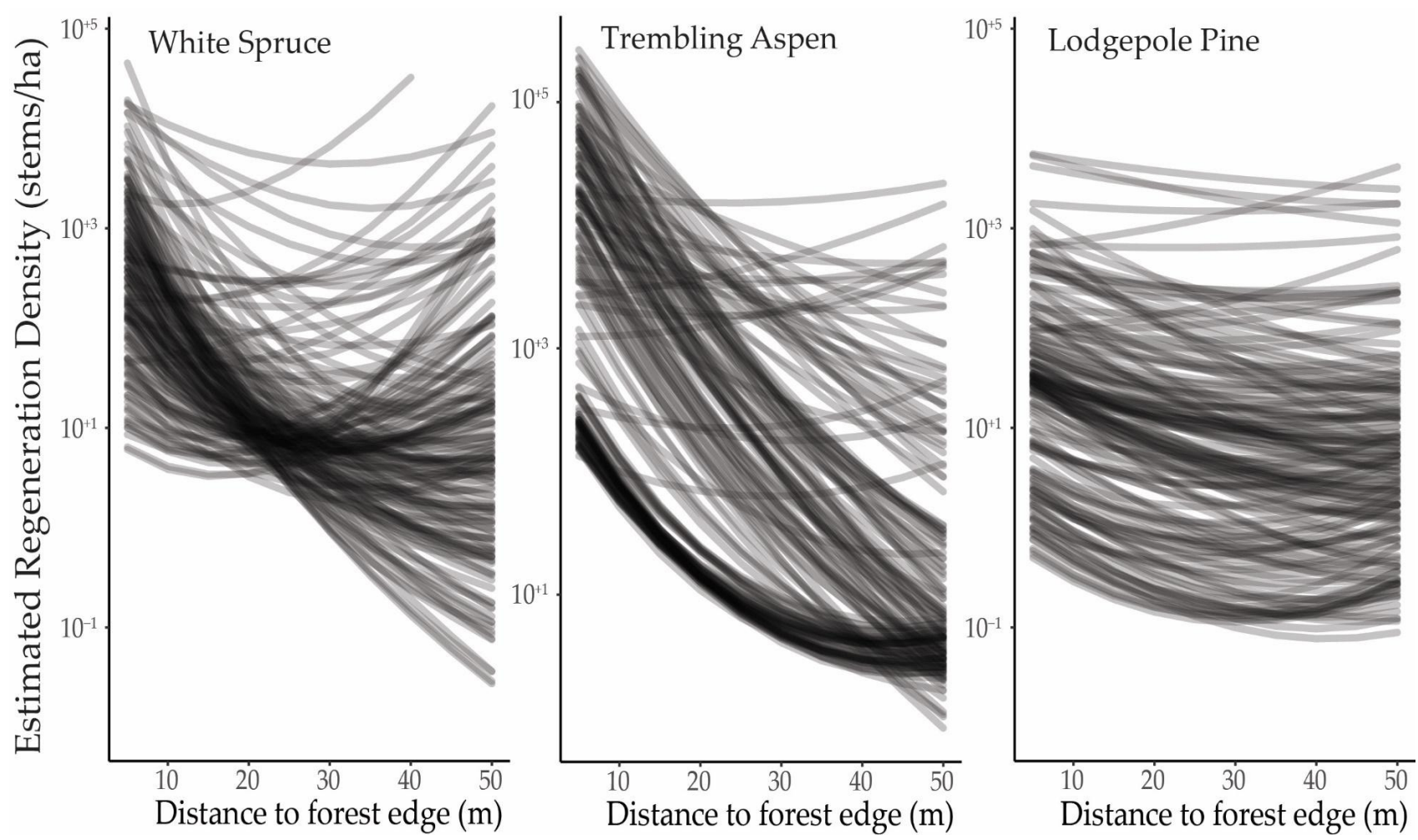

Figure 5. Effect of distance on regeneration abundance for individual transects. Note that the $y$-axis is on a logarithmic scale.Species-specific regeneration patterns generally followed the topographic distribution for each tree species (Figure 6). White spruce regeneration was highest at low elevations and on steeper slopes with east and north aspects. Trembling aspen regeneration was highest at low elevations, but did not vary much with slope or aspect. Lodgepole pine regeneration was greatest at high elevations and on southerly aspects. The models showed no topographic effects on how far lodgepole pine or trembling aspen regeneration extended into the grasslands (Figure 6). There was some indication that white spruce regeneration did not drop off as strongly with distance at higher elevations and southerly aspects, but the predicted density of regeneration at 25-50 $\mathrm{m}$ from the edge was negligible. 


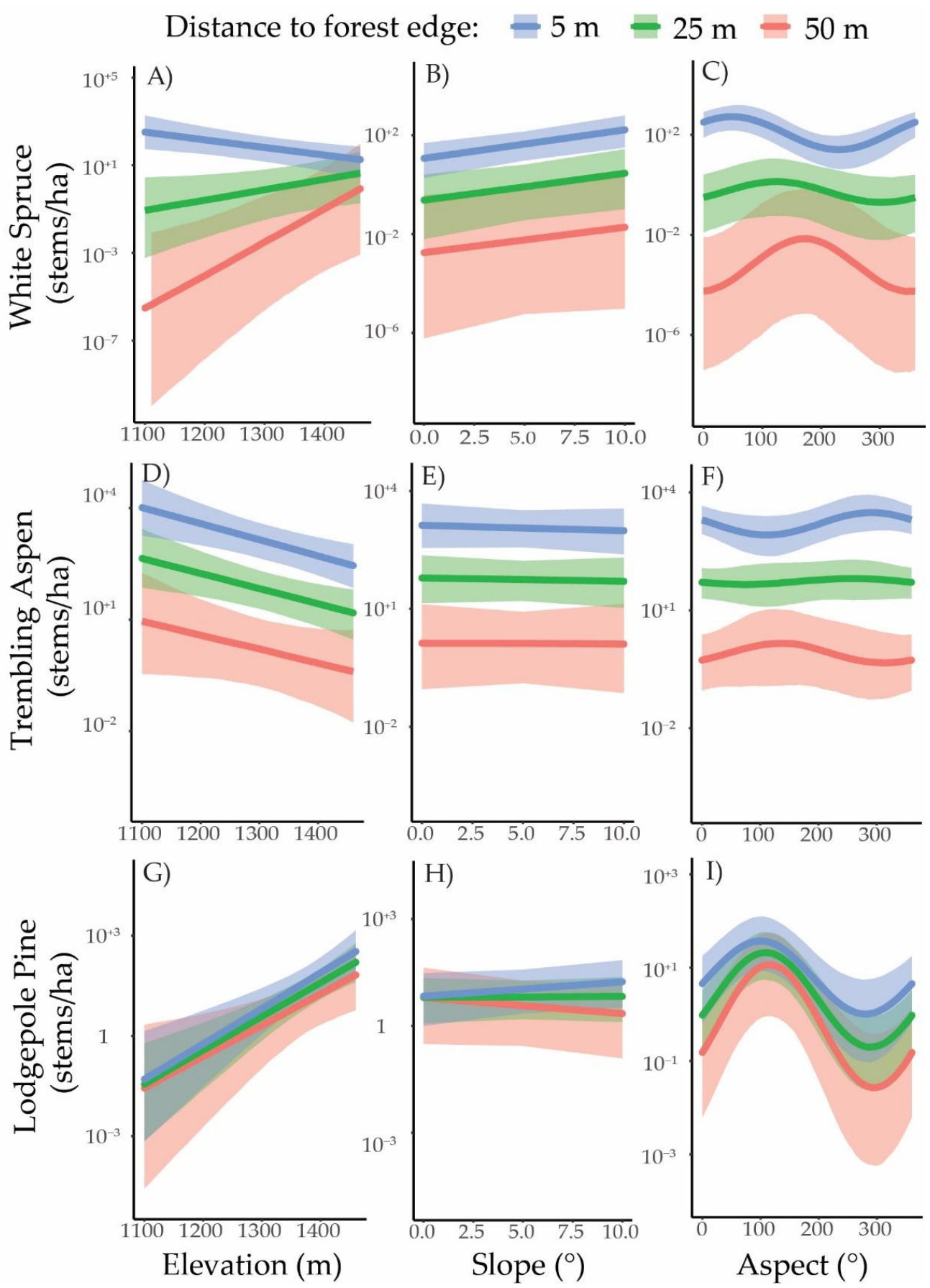

Figure 6. Topographic influence on regeneration density at $5 \mathrm{~m}, 25 \mathrm{~m}$, and $50 \mathrm{~m}$ from the forest edge for white spruce $(\mathbf{A}-\mathbf{C})$, trembling aspen $(\mathbf{D}-\mathbf{F})$, and lodgepole pine $(\mathbf{G}-\mathbf{I})$. Lines represent the posterior estimates and shaded areas around the lines represent the $95 \%$ credible interval. Panels where lines are not parallel to one another indicate that the effect of distance from the forest edge varies topographically $(\mathbf{A}, \mathbf{C})$. Note that the $y$-axis is on a logarithmic scale and ranges differ between panels.

Based on the density of scat, cattle were the dominant grazer in grassland areas within $50 \mathrm{~m}$ of the forest edge (1335 scats $/$ ha; $76 \%$ of total scat). Wild ungulates active in these areas included deer (381 scats/ha, 22\%) and elk (32 scats/ha, 2\%). Regeneration models that included and excluded effects of grazing were both found among the top-ranked models for each tree species, with relatively little difference in expected predictive ability between them $(\triangle \mathrm{LOO}=0.0-0.6$ for all species; Table 4$)$. Thus, our results do not provide 
strong evidence for either positive or negative effects of grazing on tree regeneration in grassland areas.

\section{Discussion}

\subsection{Forest Expansion and Growth}

Forest expansion has increased globally in recent decades [47], causing concern about the ecosystems into which trees are expanding and their potential impacts on ecosystem functions and services. Forests in our study area were estimated to expand by $2.8 \%$ and $1.9 \%$ over 20 years (approximately $0.12 \%$ per year), for time interval 1 and 2, respectively. This estimate of forest expansion is at the low end of woody plant expansion rates reported for North America $(<0.1-2.3 \%$ per year) and for Africa, Australia, and South America $(0.1-1.1 \%)[4,5]$, although our estimates do not include shrubs or isolated trees. There were corresponding $3.4 \%$ and $2.5 \%$ losses of grassland cover (approximately $0.15 \%$ per year) estimated for interval 1 and 2, respectively. Other studies in western North America have calculated rates of grassland loss to forest expansion approximately 2-6 times higher than we found $[2,17,25,39]$.

An earlier study on the Alberta plateau of Cypress Hills found that tree cover expanded by approximately $\sim 1 \%$ per year between 1950 and 2002 [53]. Several factors could account for the greater expansion rate in that study. Their study area had a lower initial forest area (19\%) compared with ours (54\%), which would make relative changes in forest cover appear larger. It also spanned an earlier time period when the rate of land cover change may have been higher. Methodological differences could have played a role as well, as the authors used a lower canopy cover threshold than we did, and also included patches of trees $<0.5$ ha in area.

We found that forest expansion decelerated in recent decades, from $2.8 \%$ during the 1970s-1990s period to $1.9 \%$ from the 1990s-2018. This is likely part of a fluctuating pattern that has been observed in long-term studies $[54,55]$. The fact that the rate did not increase substantially in the second interval indicates that dramatic land cover change is unlikely in the coming years. Stevens et al. [4] found faster rates of woody plant expansion in more recent studies compared with older research and some have attributed this increasing rate in the second half of the 20th century to increasing concentrations of atmospheric $\mathrm{CO}_{2}[56,57]$. The decreased rate of expansion observed in this study area does not follow that pattern, however.

The mean upper canopy height of 20-year-old (established in interval 2) and 40-year-old forests (established in interval 1) only differed by about $1 \mathrm{~m}$, and both were about $5.5 \mathrm{~m}$ shorter than pre-existing forests (Figure 4). Pre-existing forest canopies in our study had approximately $10 \%$ more cover than the newer forests, compared with a $1 \%$ difference between the newer forests from the first and second intervals. There are a couple of possible explanations for similarity between 20- and 40-year-old forests. First, areas adjacent to the grasslands contained scattered adult trees of appreciable size. As trees fill in and a continuous forest canopy is established, the upper canopy height could still be determined by the older trees that first established in the grassland. Second, increased light availability along the edge may reduce allocation to vertical growth compared with the forest interior, where access to light may be limited by taller neighbors [31]. A third explanation is succession. As a somewhat shade-tolerant species, white spruce tends to grow slowly under an established canopy. Younger forests near the grassland edge would likely be dominated by trembling aspen or lodgepole pine, with white spruce not yet having reached the canopy or approached its maximum height of 25-30 m [58]. The upper canopy height may not change dramatically until after white spruce emerges above the surrounding canopy, a process that takes much longer than 40 years [59].

\subsection{Spatial Patterns and Topographic Variation}

Most forest expansion in our study area occurred within 25-50 $\mathrm{m}$ of the forest edge. Regeneration patterns also indicated similar spatial constraints with only $32 \%$ of all regen- 
eration located further than $15 \mathrm{~m}$ into the grasslands. The strong effect of distance is likely the result of dispersal limitation and the facilitative effects of neighboring adult trees [35,60]. The increased moisture, more stable air temperatures, and decreased winds near the forest edge may be better suited to regeneration success than open grassland conditions [31,61]. Many grassland areas up to $50 \mathrm{~m}$ from the forest edge had appreciable tree cover (Figure 6), which suggests that forest expansion starts with sporadic tree establishment that, through the process of infilling, eventually reaches the $50 \%$ cover threshold we used to define forest.

Lodgepole pine and trembling aspen, which are shade-intolerant, pioneer species, may rely less on the facilitative effects of the forest edge. Of the three species in our study, lodgepole pine regeneration extended the farthest into grasslands. However, even though trembling aspen densities decreased more rapidly away from the forest edge, the proliferation of aspen suckers produced a similar regeneration density to lodgepole pine $25 \mathrm{~m}$ from the forest edge. Once established, these isolated pine trees and aspen colonies may have a nucleating effect [23], facilitating further tree regeneration in the harsher, open environment [34,35]. Isolated grassland trees also produce seed and suckers that contribute to infilling and the eventual formation of a closed forest canopy.

While dispersal from isolated trees in the grassland could lead to tree establishment even further from the forest edge, the slow rate of forest expansion observed over the last 40 years, and the low canopy height and virtual absence of tree cover in open grasslands $(0.5 \pm 2 \mathrm{~m}$ and $1 \pm 4 \%)$, indicates that successful tree establishment more than $50 \mathrm{~m}$ from a forest edge is not common.

We observed higher probabilities of forest expansion on northeast-facing slopes, flat terrain, and at lower elevations. Flatter slopes and lower elevations were also associated with taller forest canopies and greater canopy cover for newly established forests, but topographic features did not affect how far regeneration extended into grasslands. Topographic patterns in regeneration followed the landscape-level distribution of forest types across the study area. While moisture availability at lower elevations may be a factor, the most likely explanation for topographic variation in forest expansion relates to species composition and species-specific regeneration mechanisms. For example, trembling aspen, which occupies lower elevations and shallower slopes, propagates through root suckers that produce regeneration densities an order of magnitude higher than the other species. Lodgepole pine, which reproduces by seed, had a lower regeneration density and dominates at upper elevations, where less expansion was observed. White spruce, which also reproduces by seed, had a similar overall regeneration density to lodgepole pine, but it is less likely to survive in open grasslands $[29,62]$. White spruce may regenerate better after pioneer species have established in the open, as the presence of other species has been shown to reduce its climatic sensitivity $[11,63]$.

\subsection{Grazing}

No clear relationship between regeneration abundance and grazing intensity emerged in our results. Cattle do not eat many young trees as part of their diet [64]. Tramplingrelated mortality may sometimes occur [65], but not to an appreciable degree. It is possible that competition from grasses has only minor effects on tree regeneration and any beneficial effect from cattle grazing is small. Sankey et al. [16] and Fensham et al. [46] likewise found no overall trend of grazing on tree establishment, and Barnett and Stohlgren [66] found that greater densities of elk did not decrease aspen regeneration. An earlier study conducted on a portion of our study area also concluded that grazing did not substantially contribute to forest encroachment, despite a long-term negative correlation with tree establishment [53]. However, other studies have found effects of grazing on ecotone shifts $[4,26,30]$.

There are several challenges to investigating long-term impacts of grazing on tree regeneration. Clear historical records on grazing management practices are often not available $[47,66]$, and even when they are it can be difficult to separate grazing from other sources of environmental change $[1,17,24]$. While testing for a short-term relationship 
between grazer presence and regeneration density provides only a snapshot view, it could have revealed more localized effects if they were present.

\section{Conclusions}

This research quantified forest expansion across a mosaic landscape in western Canada. We estimated that rates of forest expansion were lower in the 1990s-2018 (1.9\% every 20 years) compared with the 1970s-1990s (2.8\% every 20 years) and that, overall, the annual rate of forest expansion $(0.12 \%)$ was on the low end of woody plant expansion rates calculated for North and South America, Africa, and Australia [4,5]. Forest regeneration density decreased dramatically at distances greater than $15 \mathrm{~m}$ from the forest edge, and most changes in land cover over a twenty-year period occurred $25-50 \mathrm{~m}$ from an established forest edge. Overall, forest expansion occurred through slow, sporadic establishment of trees in grasslands adjacent to the forest edge that filled over time to establish new forest areas. These findings contribute to a better understanding of the rates and patterns of forest expansion worldwide.

Supplementary Materials: The following are available online at https://www.mdpi.com/article/ 10.3390/land10121355/s1, Table S1: Specifications for aerial photo data used to assess land cover change, Table S2. Formulations for the set of candidate models. Models 1-10 were considered for all response variables. Models 11-20, which included effects of grazing, were only considered for regeneration density, Table S3. Posterior estimates and credible interval values for the selected land cover change model (model 9 in Table S2), Table S4. Posterior estimates and credible interval values for selected models estimating upper canopy height and canopy cover for forests established in time interval 1 (model 3 in Table S2), forests established in time interval 2 (models 2 and 6 in Table S2), and tree cover in grasslands within $50 \mathrm{~m}$ of the forest edge (models 8 and 10 in Table S2), Table S5. Posterior estimates and credible intervals for the selected regeneration density models (model 9 in Table S2) for white spruce, trembling aspen and lodgepole pine, Figure S1. Observed upper canopy height (95th percentile) and canopy cover of $\sim 1$-ha areas by land cover category in relation to aspect, slope and elevation. Error bars represent standard error, Figure S2. Mean regeneration density (stems/ha) from field transects of white spruce (A-C), trembling aspen (D-F), and lodgepole pine (G-I) in relation to elevation, slope and aspect, Figure S3. Variation in activity of cattle and other ungulates, as measured by scat density, by elevation, slope, and aspect, Figure S4. Relationships between tree regeneration density in grassland areas within $50 \mathrm{~m}$ of the forest edge and grazing intensity. Topographic variables appeared to explain these patterns, as an independent grazing effect was not supported by our model selection proces.

Author Contributions: Conceptualization, L.R. and M.C.V.; Data curation, L.R. and C.H.; Formal analysis, L.R. and M.C.V.; Funding acquisition, M.C.V. and L.R.; Supervision, M.C.V.; Writingoriginal draft, L.R.; Writing—review \& editing, C.H. and M.C.V. All authors have read and agreed to the published version of the manuscript.

Funding: This research was made possible through the financial support provided by the Natural Sciences and Engineering Research Council of Canada, the Saskatchewan Ministry of Parks, Culture, and Sport, the University of Regina Faculty of Graduate Studies and Research, and Mitacs. Data were provided by Tarin Resource Services Ltd., Alberta Parks, and the Saskatchewan Ministry of Parks, Culture, and Sport.

Institutional Review Board Statement: Not applicable.

Informed Consent Statement: Not applicable.

Data Availability Statement: The data presented in this study are available in the Supplementary Material.

Acknowledgments: Thank you to K. Cuthbert for assistance in collecting field data.

Conflicts of Interest: The authors declare no conflict of interest. 


\section{References}

1. Améztegui, A.; Brotons, L.; Coll, L. Land-Use Changes as Major Drivers of Mountain Pine (Pinus Uncinata Ram.) Expansion in the Pyrenees. Glob. Ecol. Biogeogr. 2010, 19, 632-641. [CrossRef]

2. Coop, J.D.; Givnish, T.J. Spatial and Temporal Patterns of Recent Forest Encroachment in Montane Grasslands of the Valles Caldera, New Mexico, USA. J. Biogeogr. 2007, 34, 914-927. [CrossRef]

3. Kadmon, R.; Harari-Kremer, R. Studying Long-Term Vegetation Dynamics Using Digital Processing of Historical Aerial Photographs. Remote Sens. Environ. 1999, 68, 164-176. [CrossRef]

4. Stevens, N.; Lehmann, C.E.R.; Murphy, B.P.; Durigan, G. Savanna Woody Encroachment Is Widespread across Three Continents. Glob. Chang. Biol. 2017, 23, 235-244. [CrossRef] [PubMed]

5. Barger, N.N.; Archer, S.R.; Campbell, J.L.; Huang, C.; Morton, J.A.; Knapp, A.K. Woody Plant Proliferation in North American Drylands: A Synthesis of Impacts on Ecosystem Carbon Balance. J. Geophys. Res. Biogeosci. 2011, 116, G00K07. [CrossRef]

6. Eldridge, D.J.; Bowker, M.A.; Maestre, F.T.; Roger, E.; Reynolds, J.F.; Whitford, W.G. Impacts of Shrub Encroachment on Ecosystem Structure and Functioning: Towards a Global Synthesis. Ecol. Lett. 2011, 14, 709-722. [CrossRef]

7. Hoekstra, J.M.; Boucher, T.M.; Ricketts, T.H.; Roberts, C. Confronting a Biome Crisis: Global Disparities of Habitat Loss and Protection. Ecol. Lett. 2005, 8, 23-29. [CrossRef]

8. King, A.W.; Dilling, L.; Zimmerman, G.P.; Fairman, D.M.; Houghton, R.A.; Marland, G.; Rose, A.Z.; Wilbanks, T.J. The First State of the Carbon Cycle Report (SOCCR): The North American Carbon Budget and Implications for the Global Carbon Cycle; U.S. Climate Change Science Program: Washington, DC, USA, 2007.

9. Archer, S.R.; Andersen, E.M.; Predick, K.I.; Schwinning, S.; Steidl, R.J.; Woods, S.R. Woody Plant Encroachment: Causes and Consequences. In Rangeland Systems: Processes, Management and Challenges; Briske, D.D., Ed.; Springer Series on Environmental Management; Springer International Publishing: Cham, Switzerland, 2017; pp. 25-84.

10. Sankaran, M.; Hanan, N.P.; Scholes, R.J.; Ratnam, J.; Augustine, D.J.; Cade, B.S.; Gignoux, J.; Higgins, S.I.; Le Roux, X.; Ludwig, F.; et al. Determinants of Woody Cover in African Savannas. Nature 2005, 438, 846-849. [CrossRef]

11. Chhin, S.; Wang, G.G. Spatial and Temporal Pattern of White Spruce Regeneration within Mixed-Grass Prairie in the Spruce Woods Provincial Park of Manitoba. J. Biogeogr. 2002, 29, 903-912. [CrossRef]

12. Chhin, S.; Wang, G.G. Growth of White Spruce, Picea Glauca, Seedlings in Relation to Microenvironmental Conditions in a Forest-Prairie Ecotone of Southwestern Manitoba. Can. Field-Nat. 2007, 121, 191-200. [CrossRef]

13. Hogg, E.H.; Brandt, J.P.; Kochtubajda, B. Factors Affecting Interannual Variation in Growth of Western Canadian Aspen Forests during 1951-2000. Can. J. For. Res. 2005, 35, 610-622. [CrossRef]

14. Fensham, R.J.; Fairfax, R.J.; Archer, S.R. Rainfall, Land Use and Woody Vegetation Cover Change in Semi-Arid Australian Savanna. J. Ecol. 2005, 93, 596-606. [CrossRef]

15. Joshi, A.A.; Ratnam, J.; Sankaran, M. Frost Maintains Forests and Grasslands as Alternate States in a Montane Tropical ForestGrassland Mosaic; but Alien Tree Invasion and Warming Can Disrupt This Balance. J. Ecol. 2020, 108, 122-132. [CrossRef]

16. Kennedy, P.G.; Sousa, W.P. Forest Encroachment into a Californian Grassland: Examining the Simultaneous Effects of Facilitation and Competition on Tree Seedling Recruitment. Oecologia 2006, 148, 464-474. [CrossRef]

17. Mast, J.N.; Veblen, T.T.; Hodgson, M.E. Tree Invasion within a Pine/Grassland Ecotone: An Approach with Historic Aerial Photography and GIS Modeling. For. Ecol. Manag. 1997, 93, 181-194. [CrossRef]

18. Naito, A.T.; Cairns, D.M. Relationships between Arctic Shrub Dynamics and Topographically Derived Hydrologic Characteristics. Environ. Res. Lett. 2011, 6, 045506. [CrossRef]

19. Wu, X.B.; Archer, S.R. Scale-Dependent Influence of Topography-Based Hydrologic Features on Patterns of Woody Plant Encroachment in Savanna Landscapes. Landsc. Ecol. 2005, 20, 733-742. [CrossRef]

20. Belsky, A.J.; Amundson, R.G.; Duxbury, J.M.; Riha, S.J.; Ali, A.R.; Mwonga, S.M. The Effects of Trees on Their Physical, Chemical and Biological Environments in a Semi-Arid Savanna in Kenya. J. Appl. Ecol. 1989, 26, 1005-1024. [CrossRef]

21. Coop, J.D.; Givnish, T.J. Constraints on Tree Seedling Establishment in Montane Grasslands of the Valles Caldera, New Mexico. Ecology 2008, 89, 1101-1111. [CrossRef] [PubMed]

22. Griffiths, R.; Madritch, M.; Swanson, A. Conifer Invasion of Forest Meadows Transforms Soil Characteristics in the Pacific Northwest. For. Ecol. Manag. 2005, 208, 347-358. [CrossRef]

23. Haugo, R.D.; Halpern, C.B. Tree Age and Tree Species Shape Positive and Negative Interactions in a Montane Meadow. Botany 2010, 88, 488-499. [CrossRef]

24. Mast, J.N.; Veblen, T.T.; Linhart, Y.B. Disturbance and Climatic Influences on Age Structure of Ponderosa Pine at the Pine/Grassland Ecotone, Colorado Front Range. J. Biogeogr. 1998, 25, 743-755. [CrossRef]

25. Bai, Y.; Broersma, K.; Thompson, D.; Ross, T.J. Landscape-Level Dynamics of Grassland-Forest Transitions in British Columbia. Rangel. Ecol. Manag. 2004, 57, 66-75. [CrossRef]

26. Dunwiddie, P.W. Recent Tree Invasion of Subalpine Meadows in the Wind River Mountains, Wyoming. Arct. Alp. Res. 1977, 9 , 393-399. [CrossRef]

27. Ducherer, K.; Bai, Y.; Thompson, D.; Broersma, K. Dynamic Responses of a British Columbian Forest-Grassland Interface to Prescribed Burning. West. N. Am. Nat. 2009, 69, 75-87. [CrossRef]

28. Hogg. Climate and the Southern Limit of the Western Canadian Boreal Forest. Can. J. For. Res. 1994, 24, 1835-1845. [CrossRef] 
29. Hogg, E.H.; Schwarz, A.G. Regeneration of Planted Conifers across Climatic Moisture Gradients on the Canadian Prairies: Implications for Distribution and Climate Change. J. Biogeogr. 1997, 24, 527-534. [CrossRef]

30. Williams-Linera, G. Vegetation Structure and Environmental Conditions of Forest Edges in Panama. J. Ecol. 1990, 78, 356-373. [CrossRef]

31. Chen, J.; Franklin, J.F.; Spies, T.A. Growing-Season Microclimatic Gradients from Clearcut Edges into Old-Growth Douglas-Fir Forests. Ecol. Appl. 1995, 5, 74-86. [CrossRef]

32. Bergès, L.; Dupouey, J.-L. Historical Ecology and Ancient Forests: Progress, Conservation Issues and Scientific Prospects, with Some Examples from the French Case. J. Veg. Sci. 2021, 32, e12846. [CrossRef]

33. Frenne, P.D.; Baeten, L.; Graae, B.J.; Brunet, J.; Wulf, M.; Orczewska, A.; Kolb, A.; Jansen, I.; Jamoneau, A.; Jacquemyn, H.; et al. Interregional Variation in the Floristic Recovery of Post-Agricultural Forests. J. Ecol. 2011, 99, 600-609. [CrossRef]

34. Bekker, M.F. Positive Feedback between Tree Establishment and Patterns of Subalpine Forest Advancement, Glacier National Park, Montana, U.S.A. Arct. Antarct. Alp. Res. 2005, 37, 97-107. [CrossRef]

35. Duarte, L.D.S.; Dos-Santos, M.M.G.; Hartz, S.M.; Pillar, V.D. Role of Nurse Plants in Araucaria Forest Expansion over Grassland in South Brazil. Austral Ecol. 2006, 31, 520-528. [CrossRef]

36. Gartzia, M.; Alados, C.L.; Pérez-Cabello, F. Assessment of the Effects of Biophysical and Anthropogenic Factors on Woody Plant Encroachment in Dense and Sparse Mountain Grasslands Based on Remote Sensing Data. Prog. Phys. Geogr. Earth Environ. 2014, 38, 201-217. [CrossRef]

37. Cienciala, E.; Mellander, P.-E.; Kučera, J.; Oplutilová, M.; Ottosson-Löfvenius, M.; Bishop, K. The Effect of a North-Facing Forest Edge on Tree Water Use in a Boreal Scots Pine Stand. Can. J. For. Res. 2002, 32, 693-702. [CrossRef]

38. Fairweather, M.L.; Geils, B.W.; Manthei, M. Aspen Decline on the Coconino National Forest. In McWilliams Michael Palacios Patsy Comps. Proceedings of the 55th Annual Western International Forest Disease Work Conference, Sedona, AZ, USA, 15-19 October 2007; Oregon Department of Forestry: Salem, OR, USA, 2008; pp. 53-62.

39. Stockdale, C.A.; Macdonald, S.E.; Higgs, E. Forest Closure and Encroachment at the Grassland Interface: A Century-Scale Analysis Using Oblique Repeat Photography. Ecosphere 2019, 10, e02774. [CrossRef]

40. Fuhlendorf, S.D.; Engle, D.M. Application of the Fire-Grazing Interaction to Restore a Shifting Mosaic on Tallgrass Prairie. J. Appl. Ecol. 2004, 41, 604-614. [CrossRef]

41. Wilcox, B.P.; Birt, A.; Fuhlendorf, S.D.; Archer, S.R. Emerging Frameworks for Understanding and Mitigating Woody Plant Encroachment in Grassy Biomes. Curr. Opin. Environ. Sustain. 2018, 32, 46-52. [CrossRef]

42. Bird, R.D. Ecology of the Aspen Parkland of Western Canada in Relation to Land Use. Public Dep. Agric. Can. 1961, 1066, 5-155.

43. Campbell, C.; Campbell, I.D.; Blyth, C.B.; McAndrews, J.H. Bison Extirpation May Have Caused Aspen Expansion in Western Canada. Ecography 1994, 17, 360-362. [CrossRef]

44. Briggs, J.M.; Hoch, G.A.; Johnson, L.C. Assessing the Rate, Mechanisms, and Consequences of the Conversion of Tallgrass Prairie to Juniperus Virginiana Forest. Ecosystems 2002, 5, 578-586. [CrossRef]

45. Soulé, P.T.; Knapp, P.A.; Grissino-Mayer, H.D. Comparative Rates of Western Juniper Afforestation in South-Central Oregon and the Role of Anthropogenic Disturbance. Prof. Geogr. 2003, 55, 43-55.

46. Sankey, T.T.; Montagne, C.; Graumlich, L.; Lawrence, R.; Nielsen, J. Twentieth Century Forest-Grassland Ecotone Shift in Montana under Differing Livestock Grazing Pressure. For. Ecol. Manag. 2006, 234, 282-292. [CrossRef]

47. Browning, D.M.; Archer, S.R. Protection from Livestock Fails to Deter Shrub Proliferation in a Desert Landscape with a History of Heavy Grazing. Ecol. Appl. 2011, 21, 1629-1642. [CrossRef]

48. Environment and Climate Change Canada. Canadian Climate Normals 1981-2010 Station Data-Climate-Environment and Climate Change Canada. Available online: https://climate.weather.gc.ca/climate_normals/results_1981_2010_e.html? searchType $=$ stnName\&txtStationName $=$ cypress + hills\&searchMethod $=$ contains\&txtCentralLatMin $=0 \&$ txtCentralLatSec $=0 \&$ txtCentralLongMin=0\&txtCentralLongSec=0\&stnID=3085\&dispBack=1 (accessed on 9 May 2021).

49. Government of Alberta. Cypress Hills Interprovincial Park Managment Plan. Available online: https://www.albertaparks.ca/ media/6493245/cypress-hills-pp-mp_june-2011.pdf (accessed on 8 September 2021).

50. Sauchyn, D.J. A Reconstruction of Holocene Geomorphology and Climate, Western Cypress Hills, Alberta and Saskatchewan. Can. J. Earth Sci. 1990, 27, 1504-1510. [CrossRef]

51. Natural Resources Canada; Treasury Board of Canada Secretariat. Canadian Digital Elevation Model, 1945-2011-Open Government Portal. Available online: https:/ / open.canada.ca/data/en/dataset/7f245e4d-76c2-4caa-951a-45d1d2051333 (accessed on 9 September 2021).

52. Roussel, J.-R.; Auty, D.; Coops, N.C.; Tompalski, P.; Goodbody, T.R.H.; Meador, A.S.; Bourdon, J.F.; de Boissieu, F.; Achim, A. lidR_ An R Package for Analysis of Airborne Laser Scanning (ALS) Data I Elsevier Enhanced Reader. Available online: https: / / reader.elsevier.com/reader/sd/pii/S0034425720304314?token=C6FB4713088DE5874DB6DDC24746B202791F87F89F4C1 E4A501D0F73E817ADBC529B815D0BDE5200C77B7F16BF2E698E\&originRegion=us-east-1\&originCreation=20210909031859 (accessed on 8 September 2021).

53. Widenmaier, K.J.; Strong, W. Tree and Forest Encroachment into Fescue Grasslands on the Cypress Hills Plateau, Southeast Alberta, Canada. For. Ecol. Manag. 2010, 259, 1870-1879. [CrossRef]

54. Browning, D.M.; Archer, S.R.; Asner, G.P.; McClaran, M.P.; Wessman, C.A. Woody Plants in Grasslands: Post-Encroachment Stand Dynamics. Ecol. Appl. 2008, 18, 928-944. [CrossRef] 
55. McClaran, M.P. A Century of Vegetation Change on the Santa Rita Experimental Range; Rocky Mountain Research Station: Ogden, UT, USA, 2003.

56. Bond, W.J.; Midgley, G.F. A Proposed CO2-Controlled Mechanism of Woody Plant Invasion in Grasslands and Savannas. Glob. Chang. Biol. 2000, 6, 865-869. [CrossRef]

57. Buitenwerf, R.; Bond, W.J.; Stevens, N.; Trollope, W.S.W. Increased Tree Densities in South African Savannas: $>50$ Years of Data Suggests $\mathrm{CO}_{2}$ as a Driver. Glob. Chang. Biol. 2012, 18, 675-684. [CrossRef]

58. Greene, D.F.; Zasada, J.C.; Sirois, L.; Kneeshaw, D.; Morin, H.; Charron, I.; Simard, M.J. A Review of the Regeneration Dynamics of North American Boreal Forest Tree Species. Can. J. For. Res. 1999, 29, 824-839. [CrossRef]

59. Gutsell, S.L.; Johnson, E.A. Accurately Ageing Trees and Examining Their Height-Growth Rates: Implications for Interpreting Forest Dynamics. J. Ecol. 2002, 90, 153-166. [CrossRef]

60. D’Odorico, P.; Fuentes, J.D.; Pockman, W.T.; Collins, S.L.; He, Y.; Medeiros, J.S.; DeWekker, S.; Litvak, M.E. Positive Feedback between Microclimate and Shrub Encroachment in the Northern Chihuahuan Desert. Ecosphere 2010, 1, art17. [CrossRef]

61. Carlson, D. Microclimate of Clear-Cut, Forest Interior, and Small Openings in Trembling Aspen Forest. Agric. For. Meteorol. 1997, 87, 313-329. [CrossRef]

62. Man, R.; Lieffers, V.J. Seasonal Photosynthetic Responses to Light and Temperature in White Spruce (Picea Glauca) Seedlings Planted under an Aspen (Populus Tremuloides) Canopy and in the Open. Tree Physiol. 1997, 17, 437-444. [CrossRef]

63. Chhin, S.; Wang, G.G. Climatic Sensitivity of a Mixed Forest Association of White Spruce and Trembling Aspen at Their Southern Range Limit. Forests 2016, 7, 235. [CrossRef]

64. Plumb, G.E.; Dodd, J.L. Foraging Ecology of Bison and Cattle on a Mixed Prairie: Implications for Natural Area Management. Ecol. Appl. 1993, 3, 631-643. [CrossRef]

65. Bork, E.W.; Carlyle, C.N.; Cahill, J.F.; Haddow, R.E.; Hudson, R.J. Disentangling Herbivore Impacts on Populus Tremuloides: A Comparison of Native Ungulates and Cattle in Canada's Aspen Parkland. Oecologia 2013, 173, 895-904. [CrossRef]

66. Madany, M.H.; West, N.E. Livestock Grazing-Fire Regime Interactions within Montane Forests of Zion National Park, Utah. Ecology 1983, 64, 661-667. [CrossRef] 